\title{
Socioeconomic Status and Survival of People with Human Immunodeficiency Virus Infection before and after the Introduction of Highly Active Antiretroviral Therapy: A Systematic Literature Review
}

Elena Pavlova-McCalla ${ }^{1}$, Mary Jo Trepka ${ }^{1 *}$, Gilbert Ramirez ${ }^{2}$ and Theophile Niyonsenga ${ }^{1}$

${ }^{1}$ Department of Epidemiology and Biostatistics, Robert Stempel College of Public Health and Social Work, Florida International University, Florida, USA ${ }^{2}$ Department of Health Policy and Management, Robert Stempel College of Public Health and Social Work, Florida International University, Florida, USA

\begin{abstract}
Background: Human immunodeficiency virus/acquired immunodeficiency disease syndrome-associated mortality contributes considerably to overall mortality rates among adults in the United States. The purpose of this review is to systematically examine conceptual approaches that have been used to evaluate the association between socioeconomic status of people infected with human immunodeficiency virus and their survival and summarize existing evidence regarding the association between socioeconomic status and mortality due to human immunodeficiency virus/acquired immunodeficiency disease syndrome.
\end{abstract}

Methods: We systematically retrieved neighborhood and individual-level studies of acquired immunodeficiency disease syndrome-related or all-cause mortality among patients diagnosed with human immunodeficiency virus that reported original data and analyzed socioeconomic status as a predictor of mortality.

Results: We included 21 studies (19 cohort and 2 case-control studies). Heterogeneity in both the conceptual approaches to socioeconomic status measurements and selection of variables for the adjustment of the measure of association precluded meta-analysis of the results. Six studies observing populations before the introduction of highly active antiretroviral therapy found that socioeconomic status was not associated with human immunodeficiency virus/acquired immunodeficiency disease syndrome mortality. In the post- highly active antiretroviral therapy period socioeconomic status was inconsistently associated with Human immunodeficiency virus/acquired immunodeficiency disease syndrome mortality risk in studies adjusting for highly active antiretroviral therapy use.

Conclusion: Further studies considering multilevel socioeconomic status measurements and controlling for treatment and clinical variables are needed to enhance understanding of the role of socioeconomic gradients on human immunodeficiency virus outcomes.

Keywords: Human Immunodeficiency Virus; Acquired Immunodeficiency Syndrome; Socioeconomic status; Systematic review; Mortality

Abbreviations: AIDS: Acquired Immunodeficiency Syndrome; ART: Antiretroviral Therapy; CD4: Cluster of Differentiation 4; HAART: Highly Active Antiretroviral Therapy; HIV: Human Immunodeficiency Virus; HR: Hazards Ratio; IDU: Injection Drug Use; MSM: Men Who have Sex with Men; NHB: Non-Hispanic Black; NHW: Non-Hispanic Whites; PWA: People with AIDS; RR: Relative Risk; SEI: Socio-Economic Index; SER: Socio-Economic Resource Index; SES: Socioeconomic Status; US: United States

\section{Introduction}

Human immunodeficiency virus/acquired immunodeficiency syndrome (HIV/AIDS) remains an important public health problem despite significant worldwide efforts to combat the disease. The availability of highly active antiretroviral therapy (HAART) in the United States (US) and other developed countries altered the progression of HIV infection and brought about a dramatic decline in mortality due to HIV/AIDS [1-4], increased the median age at death due to HIV [5], and improved life expectancy after HIV diagnosis [6]. However, the rates of decline in HIV/AIDS morbidity and mortality have flattened in recent years among all racial/ethnic groups $[7,8]$. By the end of 2009, an estimated 1,108,611 people developed AIDS in the US, and of those, over half have died [9]. Even though survival has increased markedly, HIV/AIDS continues to be one of the major causes of premature mortality in the US and young minority populations have been particularly affected. In 2007, it was the fourth leading cause of death for non-Hispanic black (NHB) males and third for NHB females aged 25-44 years, ranking higher than their respective counterparts in other racial/ethnic groups (CDC, 2010) [10-12]. Therefore, for certain groups, HIV-related mortality continues to be a particularly acute public health problem.

Early HIV testing [13-16], access to specialized care [17], and adherence to HAART [18-20] are critical for control of disease progression. Yet, explanation of evident racial/ethnic disparities in HIV/AIDS patterns requires looking at complex characteristics. Population mobility, migration, and urbanization modify interactions between susceptible and infected persons in populations [21]. In

${ }^{*}$ Corresponding author: Mary Jo Trepka, MD, MSPH, Department of Epidemiology and Biostatistics, Robert Stempel College of Public Health and Social Work, Florida International University, University Park, HLSII, Room 595, 11200 SW 8th Street, Miami, Florida, USA, Tel: (305) 348-7186; Fax: (305) 3484901; E-mail: trepkam@fiu.edu

Received June 01, 2012; Accepted July 09, 2012; Published July 20, 2012

Citation: Pavlova-McCalla E, Trepka MJ, Ramirez G, Niyonsenga T (2012) Socioeconomic Status and Survival of People with Human Immunodeficiency Virus Infection before and after the Introduction of Highly Active Antiretroviral Therapy: A Systematic Literature Review. J AIDS Clinic Res 3:163. doi:10.4172/21556113.1000163

Copyright: ( 2012 Pavlova-McCalla E, et al. This is an open-access article distributed under the terms of the Creative Commons Attribution License, which permits unrestricted use, distribution, and reproduction in any medium, provided the original author and source are credited. 
Citation: Pavlova-McCalla E, Trepka MJ, Ramirez G, Niyonsenga T (2012) Socioeconomic Status and Survival of People with Human Immunodeficiency Virus Infection before and after the Introduction of Highly Active Antiretroviral Therapy: A Systematic Literature Review. J AIDS Clinic Res 3:163. doi:10.4172/2155-6113.1000163

addition, broad challenges involving economic and social deprivation, socialization patterns, socially inflicted trauma, targeted marketing of illicit drugs, and limited access to health care may explain differences in health outcomes [22]. The facts that are nearly 1 in 4 NHBs live in poverty in the US and that the poverty rate for NHBs remains about three times that of non-Hispanic whites (NHW) may partly explain the racial/ethnic variations in the national rates of HIV/AIDS incidence [23-25]. Studies observing associations between socioeconomic status and incidence of HIV/AIDS have illustrated that problems related to poverty, including limited access to quality care; the exchange of sex for drugs, money, or to meet other needs; and increased levels of substance use can directly or indirectly increase HIV risk factors [26,27]. Queries whether the social and economic situations of HIV-infected individuals explain variations in the disease progression and survival are supported by the framework of social production of disease and political economy of health. According to this framework, a person's relative social and economic positioning shapes behavior, and the relationship between subordinate-dominant groups affects patterns of disease through material and social inequalities [28].

To date, research examining the role of SES on HIV/AIDS mortality has been scarce. In addition to the difficulty of obtaining estimates of individual-level socioeconomic measures, the limited research could be due to measurement problems arising from the lack of conceptual clarity about the essential nature of social stratification and the absence of the application of sound measurement theory to the construction of socioeconomic measures in relation to health outcomes [29]. Socioeconomic status (SES) describing a person's position in a society is a multidimensional construct [29], but due to limited resources, most health studies measure SES using a single socioeconomic variable measured at a single time point and level [30]. This may be particularly restrictive in studies of HIV infection because socioeconomic factors affecting health of HIV-infected patients change not only at different times in the life course [31], but also in the course of the disease through different causal pathways [32,33].

The present review aims to explore the conceptual approaches that have been used to examine associations between SES of individuals diagnosed with HIV/AIDS and their survival and to systematically evaluate the existing evidence regarding the association between socioeconomic gradients and patterns of HIV/AIDS mortality. Knowledge about the role of SES on premature mortality of individuals with HIV/AIDS will facilitate the tailoring of prevention programs to the needs of individuals and communities.

\section{Materials and Methods}

A comprehensive electronic search of published materials was conducted to identify conceptual and empirical studies describing associations between the measures commonly accepted in public health for evaluation of SES and survival of persons diagnosed with HIV/ AIDS. PubMed, National Library of Medicine Gateway of National Institutes of Health (NLM), Social Science Citation Index, Wilson Web-Humanities and Social Sciences Index Retrospective, FRANCIS (International Humanities and Social Studies), PsycINFO, and CINAHL Plus were searched for abstracts and full text articles published in English and other languages using the following combinations of keywords:" HIV/ AIDS, socio-economic status, survival', 'HIV/AIDS, survival, SES', 'HIV/AIDS, mortality, socioeconomic*', 'HIV/AIDS, mortality, socioeconomic index', 'HIV/AIDS, mortality, socioeconomic deprivation', 'HIV/AIDS, mortality, socioeconomic position', 'HIV/ AIDS, mortality, economic status', 'HIV, mortality, neighborhood', 'HIV, mortality, education', 'HIV, mortality, income', 'HIV, mortality, social class', 'HIV, disease course*, socioeconomic', 'HIV, mortality, deprivation index.' Papers in English, Spanish, Italian, and French were examined. In addition, the references of the retrieved publications were reviewed as part of the search.

We included studies that met the following criteria: 1) measured AIDS-related deaths or all-cause mortality among individuals infected with HIV; 2) reported original data; and 3) analyzed SES as a predictor of mortality. The exclusion criteria were studies evaluating effects of socio-economic and socio-cultural attributes on HIV/AIDS outcomes other than AIDS-related or all-cause mortality, access to care, quality of life among HIV-infected individuals, sexual behaviors, practices, and beliefs about HIV. Studies that documented non-HIV/AIDSrelated deaths and accidental deaths among HIV-infected patients were excluded from the review.

Retrieved publications were stratified by the study observation period because the introduction of the effective therapeutic intervention of HAART in 1996 in the US, Canada, Europe, and Latin American countries [4,34,35]. For the reports that studied cohorts until 1996, materials were considered as covering pre-HAART period (before introduction of HAART), and for the evaluations where subjects were followed after 1996 published research was assessed as encompassing post-HAART period (when HAART became widely available). Further, we abstracted the key concepts used in the studies for SES assessments and listed them according to the level (i.e. individual vs. community) of data collection (Table1). We selected adjusted measures of association for the studies that reported both crude and adjusted measures.

Using statistical software STATA version 10 (StataCorp LP, College Station, Texas), we estimated the magnitude of the overall heterogeneity of the studies and the index of heterogeneity after stratifying studies along various lines. We applied the methodology used by other investigators [36] to retain only the hazard ratios (HRs) and relative risks (RRs) comparing lowest and highest categories when SES variables were defined in terms of quintile or levels (e.g., level I,II,III,IV). If there was more than one socioeconomic variable, we first analyzed socioeconomic resource (SER) index or socio-economic index (SEI), if present, because these are composite measures. If information on the index was not available, income and poverty status were considered next and then employment status, occupation, and education level. Income was chosen over education if both present, because income is a realized resource and education allows potential access to the desired resources [29]. However, studies of post-HAART period evaluating effects of higher SES versus low (when different SES determinants were combined) showed that the variation in effect size was 84.1 percent. The assessment of studies for pre-HAART period examining effects of lower SES vs. high with combination of SES indicators produced similar findings. Stratifications on a particular variable of SES (such as income, education level, SEI) were performed, and these too demonstrated a statistically significant high level of heterogeneity. After multiple stratifications, it became apparent that the degree of heterogeneity among studies was too large to be explained and, therefore, a decision was made that meta-analysis would not be conducted.

\section{Literature Search}

Of the 314 studies found using the keywords, 54 were deemed to be relevant (Figure 1). Eight cross-sectional [37-44] and eight ecologic studies [45-52] were excluded from the analysis because they examined absolute and relative differences in mortality risk for HIV/AIDS according to the socioeconomic characteristics of the area of patients' residence at the time of AIDS diagnosis. Therefore, it was not possible 
Citation: Pavlova-McCalla E, Trepka MJ, Ramirez G, Niyonsenga T (2012) Socioeconomic Status and Survival of People with Human Immunodeficiency Virus Infection before and after the Introduction of Highly Active Antiretroviral Therapy: A Systematic Literature Review. J AIDS Clinic Res 3:163. doi:10.4172/2155-6113.1000163

Page 3 of 5

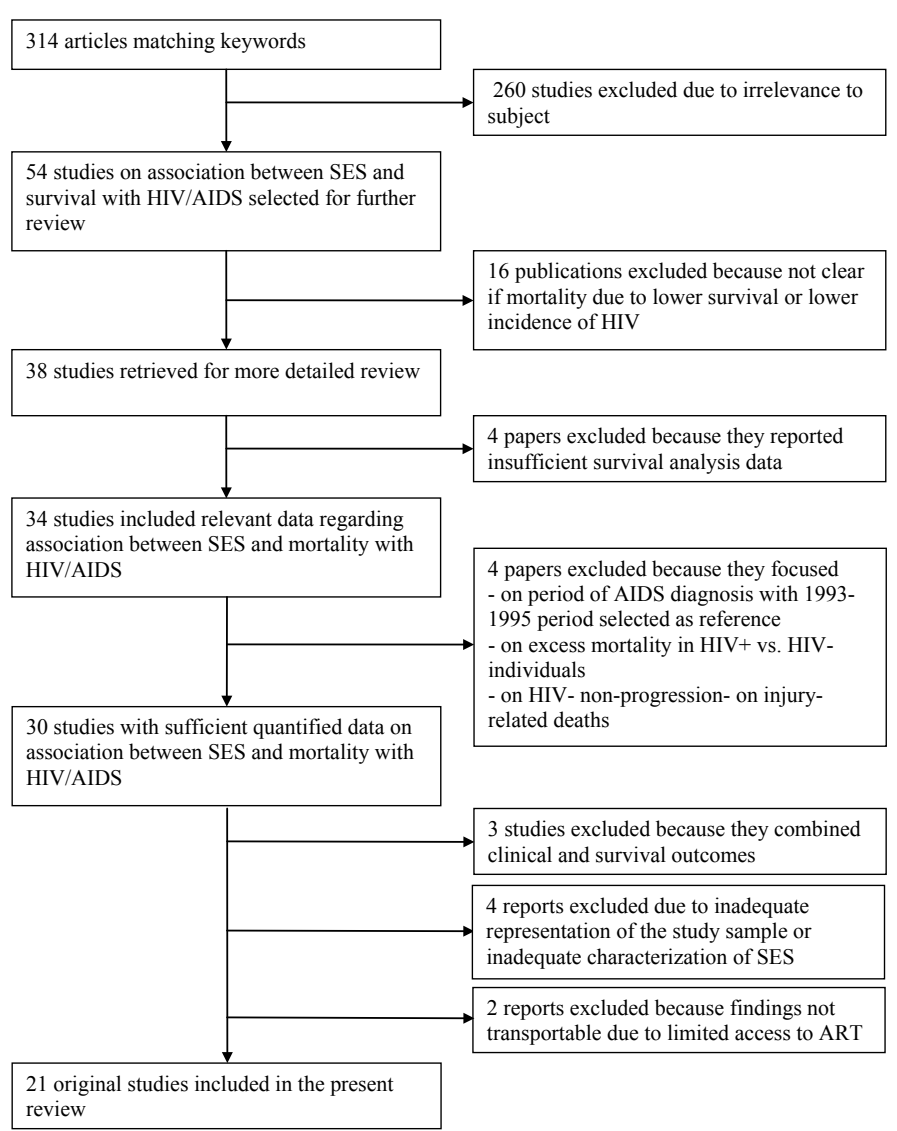

Figure 1: Study selection process in a literature review of the relation between SES and survival of individuals with HIVIAIDS.

to determine the extent of mortality due to poor survival of people with HIV/AIDS versus differences in HIV incidence and prevalence by socioeconomic group. Four publications were not considered for the analysis because they provided insufficient survival analysis data [53$56]$.

One study was excluded because in comparison of survival probability among persons with AIDS (PWA) at 24 months after AIDS diagnosis significant differences in the AIDS incidence for low and high income levels were not adequately addressed [57]. This study also reported mortality risk for the 2-year periods before and after introduction of HAART with 1993-1995 period selected as reference mainly showing effects of HAART rather than magnitude of the problem in relation to SES. Another was excluded because the excess mortality in HIV-positive patients according to socio-demographic characteristics was reported in relation to a HIV-negative cohort [58]. A Swiss study was excluded because it evaluated social co-factors of HIVnon-progression but not mortality [59]. A cohort study on mortality among HIV-infected participants in the Women's Interagency HIV Study and the Multicenter AIDS Cohort Study were excluded because it focused only on accident- and injury-related deaths [60].

Three reports were eliminated because they combined death with clinical outcomes (e.g., all-cause hospitalization and death/ clinical progression) so it was not possible to separate the effect of SES on death from other outcomes [61-63]. One report was excluded because of concern that the outcome of hospital mortality and the measure of SES type of admission as a proxy for individual SES would limit the generalizability of findings [64]. Concerns regarding nonrepresentativeness of the study sample lead us to exclude one US study that explored relationships between crack use and HIV disease outcomes among women while evaluating income and education as potential confounders [65]. Similarly, a Canadian report examining effects of self-reported income on mortality among HIV-infected MSM and a Spanish study evaluating role of education on mortality risk among HIV-infected IDUs were removed from this review due to limitations involving the cohorts with one transmission mode $[66,67]$.

Two studies done in African countries were excluded because of the generalizability concerns arising when results are compared between "high" and "low" income countries and when there is inadequate information on differentials regarding definitions of SES and modifying effects of countries' social contexts characterized by high levels of economic inequality and limited access to HAART. The first of these studies, conducted in South Africa, compared the hazards of all-cause death in treatment-naïve HIV-infected adults initiating ART and having some monthly income versus no monthly income during one-year follow-up [68]. It was not clear if the mortality was related to the earned income/government disability grants or continuous access to health care and the disease stage when patients became eligible for disability grants. The second study, carried out in Rwanda, was limited to only ART-naïve HIV-positive women of childbearing age and found low household income as a statistically significant independent predictor of mortality [69]. Thus, 21 publications of the period between 1992 and 2009 were included in the present review (Table 1). 
Citation: Pavlova-McCalla E, Trepka MJ, Ramirez G, Niyonsenga T (2012) Socioeconomic Status and Survival of People with Human Immunodeficiency Virus Infection before and after the Introduction of Highly Active Antiretroviral Therapy: A Systematic Literature Review. J AIDS Clinic Res 3:163. doi:10.4172/2155-6113.1000163

Page 4 of 5

\begin{tabular}{|c|c|c|c|c|c|c|c|c|}
\hline $\begin{array}{l}\text { Study name and } \\
\text { year of publication }\end{array}$ & $\begin{array}{l}\text { Country of } \\
\text { study }\end{array}$ & Study design & $\begin{array}{l}\text { Period of } \\
\text { observation }\end{array}$ & $\begin{array}{l}\text { Population } \\
\text { sample }\end{array}$ & $\begin{array}{l}\text { Source of } \\
\text { SES data }\end{array}$ & Measure of association & SES variable & $\begin{array}{l}\text { Reported value } \\
\text { of the association } \\
\text { measure }\end{array}$ \\
\hline \multicolumn{9}{|l|}{ Pre-HAART period } \\
\hline $\begin{array}{l}\text { 1.Chaisson et al. } \\
1995 \text { [70] }\end{array}$ & USA & Prospective cohort & 1989-1994 & $\begin{array}{l}1372 \text { HIV- } \\
\text { infected } \\
\text { patients }\end{array}$ & Self-report & Crude RR & $\begin{array}{l}\text { Income } \\
\text { Employment } \\
\text { Education }\end{array}$ & $\begin{array}{l}0.98(0.78-1.22) \\
0.77(0.67-0.89)^{*} \\
1.15(0.92-1.43)\end{array}$ \\
\hline $\begin{array}{l}\text { 2.Palombi et al. } \\
1997 \text { [71] }\end{array}$ & Italy & Prospective cohort & $1992-1994$ & 168 PWA & Self-report & Crude RR & SER index & $1.02(p$-value $=.8)$ \\
\hline $\begin{array}{l}\text { 3.Katz et al. } \\
\text { 1998[72] }\end{array}$ & USA & $\begin{array}{l}\text { Retrospective } \\
\text { cohort }\end{array}$ & $1985-1995$ & 18,167 PWA & $\begin{array}{l}\text { Census } \\
\text { block group }\end{array}$ & $\begin{array}{l}\text { HR adjusted for gender, age, } \\
\text { ethnicity, risk group, site \& } \\
\text { period of AIDS diagnosis, } \\
\text { clinical variables }\end{array}$ & $\begin{array}{l}\text { Poverty } \\
\text { Working class } \\
\text { Education }\end{array}$ & $\begin{array}{l}1.03(0.97-1.08) \\
1.03(0.98-1.08) \\
0.96(0.9-1.01)\end{array}$ \\
\hline $\begin{array}{l}\text { 4.Lee \& Rotheram- } \\
\text { Borus } 2001 \text { [73] }\end{array}$ & USA & Prospective cohort & 1993-1995 & $\begin{array}{l}307 \text { HIV- } \\
\text { infected parents } \\
\text { of adolescent } \\
\text { children }\end{array}$ & Self-report & Crude RR & $\begin{array}{l}\text { Education } \\
\text { Financial status } \\
\text { Social support }\end{array}$ & $\begin{array}{l}1.43(1.01-2.07)^{*} \\
1.51(0.90-2.54) \\
0.77(0.64-0.93)^{*}\end{array}$ \\
\hline \multicolumn{9}{|c|}{ Studies comparing pre-HAART and post-HAART periods } \\
\hline $\begin{array}{l}\text { 5. Rapiti et al. } 2000 \\
\text { [74] }\end{array}$ & Italy & $\begin{array}{l}\text { Retrospective } \\
\text { cohort }\end{array}$ & $\begin{array}{l}1993-1995 \\
\& \\
1996-1998\end{array}$ & 1,474 PWA & $\begin{array}{l}\text { Census } \\
\text { block }\end{array}$ & $\begin{array}{l}\text { HR adjusted for age, gender, } \\
\text { CD4 count at diagnosis, risk } \\
\text { factor, AIDS-defining illness, } \\
\text { center of diagnosis }\end{array}$ & SES index & $\begin{array}{l}1.08(0.83-1.38) \\
(1993-1995) \\
2.67(1.28-5.6)^{*} \\
(1996-1998)\end{array}$ \\
\hline $\begin{array}{l}\text { 6.McFarland et al. } \\
2003 \text { [35] }\end{array}$ & USA & $\begin{array}{l}\text { Retrospective } \\
\text { cohort }\end{array}$ & $\begin{array}{l}1980-1995 \\
\& \\
1996-2001\end{array}$ & $\begin{array}{l}2918 \text { HIV- } \\
\text { infected } \\
\text { patients }\end{array}$ & $\begin{array}{l}\text { Census } \\
\text { block }\end{array}$ & $\begin{array}{l}\text { HR adjusted for age, CD } 4 \\
\text { count, IDU status, HAART }\end{array}$ & Income & $\begin{array}{l}0.99(0.98-1.00) \\
(1980-1995) \\
0.93(0.86-1.01) \\
(1996-2001)\end{array}$ \\
\hline \multicolumn{9}{|l|}{ Post-HAART period } \\
\hline $\begin{array}{l}\text { 7. Lieb et al. } 2002 \\
\text { [74] }\end{array}$ & USA & $\begin{array}{l}\text { Retrospective case- } \\
\text { control }\end{array}$ & 1999 & $\begin{array}{l}120 \text { HIV- } \\
\text { infected cases } \\
\text { who died } \\
240 \text { HIV- } \\
\text { infected } \\
\text { controls alive }\end{array}$ & \multicolumn{2}{|l|}{ Self-report } & $\begin{array}{l}\text { Living situation } \\
\text { Homelessness } \\
\text { Insurance } \\
\text { (Medicaid vs. } \\
\text { Ryan White) }\end{array}$ & $\begin{array}{l}2.70(1.45-5.02)^{*} \\
2.93(1.20-7.15)^{*} \\
3.09(1.75-5.46)^{*}\end{array}$ \\
\hline $\begin{array}{l}\text { 8. Wood et al. } 2002 \\
\text { [75] }\end{array}$ & Canada & Prospective cohort & $1996-2000$ & $\begin{array}{l}1408 \text { HIV- } \\
\text { infected }\end{array}$ & Census track & $\begin{array}{l}\text { RR adjusted for age, } \\
\text { ART adherence, history } \\
\text { of IDU, CD4 count, viral } \\
\text { load, baseline AIDS }\end{array}$ & Income & $2.03(1.32-3.12)^{\star}$ \\
\hline $\begin{array}{l}\text { 9. Young et al. } 2004 \\
\text { [76] }\end{array}$ & Switzerland & Prospective cohort & 2002 & $\begin{array}{l}3736 \text { HIV- } \\
\text { infected } \\
\text { patients }\end{array}$ & Self-report & $\begin{array}{l}\text { HR adjusted for age, } \\
\text { sex, transmission } \\
\text { group, viral load, CD4 } \\
\text { count, disease stage, } \\
\text { ART, education. }\end{array}$ & $\begin{array}{l}\text { Stable } \\
\text { partnership }\end{array}$ & $0.59(0.44-0.79)^{*}$ \\
\hline $\begin{array}{l}\text { 10.Cunningham et } \\
\text { al. } 2005 \text { [77] }\end{array}$ & USA & Prospective cohort & $1996-2000$ & $\begin{array}{l}2864 \text { HIV- } \\
\text { infected } \\
\text { patients }\end{array}$ & \multicolumn{2}{|r|}{$\begin{array}{l}\text { HR adjusted for age, } \\
\text { gender, CD4 count, risk } \\
\text { factor, homelessness, } \\
\text { region of receiving } \\
\text { care, clinical stage, } \\
\text { ART }\end{array}$} & $\begin{array}{l}\text { Wealth (none vs. } \\
\$ 50,000) \\
\text { Income }(\$ 10,000 \\
\text { vs. } \$ 25,000) \\
\text { Education (no } \\
\text { high school } \\
\text { degree) } \\
\text { Unemployment } \\
\text { Insurance (none } \\
\text { vs. private) } \\
\text { Homelessness }\end{array}$ & $\begin{array}{l}1.81(1.09-3.00)^{*} \\
0.78(0.56-1.08) \\
1.52(1.14-2.02)^{*} \\
\\
1.44(1.07-1.95)^{*} \\
0.62(0.44-0.88)^{*} \\
0.99(0.7-1.4)\end{array}$ \\
\hline $\begin{array}{l}\text { 11.Kozinetz et al. } \\
2005 \text { [78] }\end{array}$ & Romania & Prospective cohort & $1999-2001$ & $\begin{array}{l}333 \text { HIV- } \\
\text { infected } \\
\text { children }\end{array}$ & \multicolumn{2}{|r|}{$\begin{array}{l}\text { HR adjusted for AIDS } \\
\text { at baseline }\end{array}$} & $\begin{array}{l}\text { Education: } \\
\text { Father's } \\
\text { Mother's } \\
\text { Unemployment }\end{array}$ & $\begin{array}{l}0.4(0.2-0.8)^{*} \\
0.3(0.1-1.0) \\
3.6(1.1-11.5)^{*}\end{array}$ \\
\hline $\begin{array}{l}\text { 12. Palange et al. } \\
2005 \text { [79] }\end{array}$ & Italy & $\begin{array}{l}\text { Retrospective } \\
\text { cohort }\end{array}$ & 1996-2002 & 1,368 PWA & \multicolumn{2}{|r|}{$\begin{array}{l}\text { HR adjusted for age, } \\
\text { gender, risk factor, } \\
\text { period and hospital of } \\
\text { diagnosis, CD4 count, } \\
\text { AIDS-defining illness }\end{array}$} & $\begin{array}{l}\text { SES level } \\
\text { Income }\end{array}$ & $\begin{array}{l}1.09(0.77-1.54) \\
1.38(0.96-1.98)\end{array}$ \\
\hline $\begin{array}{l}\text { 13.Jain et al. } 2006 \\
\text { [80] }\end{array}$ & USA & $\begin{array}{l}\text { Retrospective } \\
\text { cohort }\end{array}$ & 1996-2002 & 5007 PWA & Medical record & $\begin{array}{l}\text { HR adjusted for } \\
\text { HAART use, OI at AIDS } \\
\text { diagnosis, age, race, } \\
\text { risk factor }\end{array}$ & $\begin{array}{l}\text { Insurance } \\
\text { (private vs. } \\
\text { public) }\end{array}$ & $0.55(0.5-0.6)$ \\
\hline
\end{tabular}


Citation: Pavlova-McCalla E, Trepka MJ, Ramirez G, Niyonsenga T (2012) Socioeconomic Status and Survival of People with Human Immunodeficiency Virus Infection before and after the Introduction of Highly Active Antiretroviral Therapy: A Systematic Literature Review. J AIDS Clinic Res 3:163. doi:10.4172/2155-6113.1000163

Page 5 of 5

\begin{tabular}{|c|c|c|c|c|c|c|c|c|}
\hline $\begin{array}{l}\text { 14.Delpierre et al. } \\
2008 \text { [81] }\end{array}$ & France & Prospective cohort & $1996-2006$ & $\begin{array}{l}6805 \text { HIV- } \\
\text { infected } \\
\text { patients }\end{array}$ & Self-report & $\begin{array}{l}\text { HR adjusted for period } \\
\text { of HIV diagnosis, } \\
\text { medical center, age, } \\
\text { risk factor, ART }\end{array}$ & Unemployment & $3.75(2.11-6.6)^{*}$ \\
\hline $\begin{array}{l}\text { 15.Liotta et al. } 2008 \\
\text { [82] }\end{array}$ & Italy & Prospective cohort & $\begin{array}{l}1994-2005 \\
\& \\
1996-2005\end{array}$ & $\begin{array}{l}382 \text { HIV- } \\
\text { infected } \\
\text { patients } \\
161 \text { HIV- } \\
\text { infected } \\
\text { patients }\end{array}$ & Self-report & $\begin{array}{l}\text { Crude RR } \\
\text { RR adjusted for clinical } \\
\text { staging, CD4 count }\end{array}$ & $\begin{array}{l}\text { Housing } \\
\text { Education } \\
\text { SEl }\end{array}$ & $\begin{array}{l}1.91(1.15-3.17)^{*} \\
0.71(0.58-0.87)^{*} \\
4.14(1.28-13.4)^{*}\end{array}$ \\
\hline $\begin{array}{l}\text { 16. Joy et al. } 2008 \\
\text { [83] }\end{array}$ & Canada & Prospective cohort & $1997-2005$ & $\begin{array}{l}2168 \text { HIV- } \\
\text { infected } \\
\text { patients }\end{array}$ & Census track & $\begin{array}{l}\text { Crude HR } \\
\text { HR adjusted for age, } \\
\text { CD4 count, viral load, } \\
\text { adherence, late access } \\
\text { to ART }\end{array}$ & $\begin{array}{l}\text { Unemployment } \\
\text { Income } \\
\text { Poverty } \\
\text { Education }\end{array}$ & $\begin{array}{l}1.53(1.28-1.78)^{*} \\
0.95(0.94-0.97)^{*} \\
1.07(1.01-1.13)^{*} \\
0.80(0.71-0.91)^{*}\end{array}$ \\
\hline $\begin{array}{l}\text { 17.McDavid- } \\
\text { Harrison et al. } 2008 \\
\text { [84] }\end{array}$ & USA & $\begin{array}{l}\text { Prospective- } \\
\text { retrospective cohort }\end{array}$ & 1996-2006 & $\begin{array}{l}\text { HIV-infected } \\
174,569 \text { men \& } \\
74,128 \text { women }\end{array}$ & $\begin{array}{l}\text { Census county } \\
\text { level }\end{array}$ & $\begin{array}{l}\text { RR adjusted for time } \\
\text { from HIV diagnosis, } \\
\text { age, race/ethnicity, risk } \\
\text { factor, CD4 count, AIDS }\end{array}$ & $\begin{array}{l}\text { Poverty: } \\
\text { for men } \\
\text { for women }\end{array}$ & $\begin{array}{l}1.3(1.16-1.47)^{*} \\
1.77(1.43-2.20)^{*}\end{array}$ \\
\hline $\begin{array}{l}\text { 18.Chen et al. } 2009 \\
\text { [85] }\end{array}$ & USA & & 1996-2004 & $\begin{array}{l}\text { PWA } 266 \text { cases } \\
\& 1173 \text { controls }\end{array}$ & Medical records & $\begin{array}{l}\text { OR adjusted for age, } \\
\text { year of diagnosis, } \\
\text { stage of disease, year } \\
\text { of HAART initiation \& } \\
\text { regimen }\end{array}$ & $\begin{array}{l}\text { Insurance (public } \\
\text { vs. private) }\end{array}$ & $2.80(1.77-4.42)^{*}$ \\
\hline $\begin{array}{l}\text { 19.Druyts et al. } 2009 \\
\text { [86] }\end{array}$ & Canada & Prospective cohort & $1997-2005$ & $\begin{array}{l}533 \text { HIV- } \\
\text { infected } \\
\text { patients }\end{array}$ & Census track & Crude HR & $\begin{array}{l}\text { Unemployment } \\
\text { Education } \\
\text { Income }\end{array}$ & $\begin{array}{l}2.2(1.67-2.89)^{*} \\
0.6(0.5-0.73)^{\star} \\
1.29(1.17-1.42)^{*}\end{array}$ \\
\hline $\begin{array}{l}\text { 20.Silverberg et al. } \\
2009 \text { [87] }\end{array}$ & USA & $\begin{array}{l}\text { Retrospective } \\
\text { cohort }\end{array}$ & 1996-2005 & $\begin{array}{l}4686 \text { HIV- } \\
\text { infected } \\
\text { patients }\end{array}$ & $\begin{array}{l}\text { Census track } \\
\text { Medical record }\end{array}$ & Crude HR & $\begin{array}{l}\text { Education } \\
\text { Income } \\
\text { Insurance }\end{array}$ & $\begin{array}{l}0.85(0.62-1.15) \\
0.78(0.53-1.15) \\
1.78(1.28-2.48)^{*}\end{array}$ \\
\hline $\begin{array}{l}\text { 21. Arnold et al. } \\
2009 \text { [88] }\end{array}$ & USA & $\begin{array}{l}\text { Prospective- } \\
\text { retrospective cohort }\end{array}$ & $1996-2006$ & 4211 PWA & Census zip code & $\begin{array}{l}\text { HR adjusted for age, } \\
\text { race/ethnicity, CD4 } \\
\text { count, risk factor, ART } \\
\text { initiation }\end{array}$ & $\begin{array}{l}\text { Neighborhood } \\
\text { socioeconomic } \\
\text { context } \\
\text { Insurance } \\
\text { (private vs. none) }\end{array}$ & $\begin{array}{l}0.85(0.67-1.07) \\
0.65(0.52-0.8)^{*}\end{array}$ \\
\hline
\end{tabular}

* Statistically significant association

Abbreviations: ART: Antiretroviral Therapy; HAART: Highly Active Antiretroviral Therapy; HARS: HIVIAIDS Reporting System; IDU: Intravenous Drug User; PWA: Persons with AIDS; SEI: Socioeconomic Index; SER Index: Socioeconomic Resource Index; Adj: Adjusted; HR: Hazard Ratio; Het: Heterosexual; Lev: Level of SES; MSM: Men Who Have Sex with Men; OR: Odds Ratio; RR: Relative Risk

Table 1: Characteristics of the selected studies.

\section{Results}

Of the 21 studies included in this review, 14 originated from North America and seven from Europe (Table 1). Four studies examined effects of SES on mortality with HIV/AIDS in the years of pre-HAART period [70-73]. Fifteen studies provided an assessment of SES in relation to survival in HIV-infected patients during the years of commercial availability of HAART [74-88]. Two studies $[34,35]$ evaluated the impact of SES on survival with HIV/AIDS in both periods. Investigators used either patients' self-report of the socioeconomic determinants or linkage of the individuals' residence at the time of diagnosis with the census data. Understandably, cost and difficulties in obtaining individual SES data cause researchers' reliance on census data as a surrogate for SES assessment. However, studies with the area-level of SES often failed to specify their conceptual approaches as to whether the census data were applied as a proxy of individual SES or as an assessment of contextual socioeconomic effect. There were no studies with multilevel SES measurements.

While efforts to operationalize SES continue to evolve, current SES assessment in relation to health generally relies on data from occupational position, education, income, poverty status, or any combination of these measures [29]. The present review of studies on the relationship between SES and mortality risk among patients with HIV/AIDS confirmed the consistency of this approach. Most of the studies included in the review used more than one of the common determinants to measure SES. Nine reports $[34,35,71,75,76,80,81,84,85]$ presented one arbitrarily selected measure to quantify the association between SES and mortality among people with HIV/AIDS. Education was the most frequently used measure of SES followed by income, and employment status (Table 1). The most common rationale for the selection of a particular socioeconomic measure in the reports was that it had been adopted in the past and had high predictive validity. A calculated SES index was used in five studies $[34,71,79,82,88]$ because of a perception that a complex index discriminates better than its components. Homelessness and access to health insurance or the type of health insurance as a factor affecting survival with HIV/AIDS was considered only in the US studies of post-HAART period indicating the importance of these variables in the pathways between effective therapy initiation and survival.

Studies also differ in terms of studied population. Seven reports provided data on survival of persons with AIDS (PWAs) only $[34,71,72,79,80,85,88]$, one examined survival of HIV-infected parents of adolescents [73], one looked at survival in HIV-infected children [78], and the remaining studies assessed HIV-infected patients of both genders and various age groups (Table 1). While the majority of retrieved publications looked at all-cause mortality in individuals diagnosed with HIV/AIDS, two Canadian reports [75,83] and one US study [80] covering the post-HAART period described HIV/ AIDS-related mortality. Crude HR or RR of death was reported in eight studies and adjusted measures of association were found in the remaining (Table1). 
Citation: Pavlova-McCalla E, Trepka MJ, Ramirez G, Niyonsenga T (2012) Socioeconomic Status and Survival of People with Human Immunodeficiency Virus Infection before and after the Introduction of Highly Active Antiretroviral Therapy: A Systematic Literature Review. J AIDS Clinic Res 3:163. doi:10.4172/2155-6113.1000163

Page 6 of 5

\section{Studies of Pre-HAART Period}

Four retrieved studies of pre-HAART period evaluated the risk for mortality in relation to SES in samples of individuals with the range of mean ages from 22 to 39 years and the range of median follow-up from 16.1 months to 28 months [70-73]. Significant association between education and mortality in HIV-infected patients was found only in one US study [73] which found that adults without a high school diploma were at a higher risk of death. The same study found that perceived financial status (comfortable vs. very poor) was not associated with mortality, but availability of social support significantly decreased risk of death in the cohort of parents with adolescent children. While education partly serves as an indicator of social capital, the key factor of material capital, income, did not affect mortality in a large population of HIV-infected patients with different transmission modes [70]. However, in the same study, an indicator of human capital, employment status at baseline, was a statistically significant protective factor for mortality with HIV/AIDS in crude analysis [70].

One Italian study calculated a composite socioeconomic measure including variables of income and social support and did not find statistically significant effects of socioeconomic resource index (SER) on mortality among PWA [71]. These results were consistent with the findings of the only study of the pre-HAART period that adjusted the measure of association for demographic and clinical variables. Using census block group-level socioeconomic data, this study did not find statistically significant association between mortality in persons diagnosed with AIDS and living in a neighborhood characterized by poverty, working class occupation, or low educational level [72].

\section{Studies of post-HAART period}

Included in the review, 15 reports of post-HAART period examined relationships between SES and all-cause mortality and HIV/ AIDS-related mortality among HIV-infected patients with the mean age ranging from 11 to 42.5 years and the median follow-up ranging from 12 months to 8.6 years [74-88]. The composite index of one of these studies was based on the variables of availability of stable income, owned residential property, the need to receive social support, and the effective availability of this support in the past and at the time of interview [82]. Measured by this index, low SES significantly increased mortality risk of individuals diagnosed with HIV after adjustments for clinical variables [82]. In contrast, SES measured at area-level by a composite index was not associated with increased mortality in PWAs after adjustments for demographic and clinical variables, stage of the disease, and ART initiation $[79,88]$.

Low household income was a significant predictor of mortality among patients with HIV/AIDS in three Canadian studies, a setting with universal access to health care $[75,83,86]$. However, one study with individually collected SES data did not find an association between income and HIV/AIDS mortality risk [77]. The lack of such association was supported in two reports that applied area-level of SES data: a US study evaluating unadjusted risk of death in HIV-infected patients [87] and an Italian study examining mortality among PWA after adjustments for relevant variables [79]. Only one US study assessed wealth. Selfreported lack of accumulated assets in the population-based sample of people with HIV/AIDS was associated with statistically significant increased risk for all-cause and HIV-related mortality even after adjustments for sociodemographic, clinical, and treatment variables [77].

Five studies carried out in different countries indicated that education beyond a high school degree was a statistically significant protective factor for all-cause and HIV/AIDS-related mortality $[77,78,82,83,86]$, and one report showed no significant association with education [87]. Poverty as the area-level SES factor was positively associated with an increased risk of death in HIV-infected patients even after adjustments for age, clinical and treatment variables $[83,84]$. The only study that examined the effect of social context on survival of HIVinfected children found that maternal unemployment was associated with lower survival after adjustment for baseline AIDS diagnosis [78] Lack of employment, an important dimension of maternal, social, and human capital, was found to be associated with an increased risk for HIV/AIDS mortality in four other studies applying this measure after adjusting for demographic, clinical and treatments factors $[77,81,83,86]$.

The effects of social capital indicators were also significant. Stable partnership was a protective factor for mortality in a Swiss cohort of HIV-infected patients after adjustments for education, ART, demographic and clinical variables [76]. Living situation characterized by unmarried status and not living with a partner was a significant predictor of mortality in a case-control study [74]. The same casecontrol study demonstrated that homelessness increased the risk of death in patients with HIV, but the association was not assessed for potential confounders. Another US study using an adjusted measure of association between homelessness and HIV/AIDS mortality risk found no statistically significant association [77].

Six studies used type of insurance as the measure for SES. An earlier publication of the post-HAART period showed that HIV-infected patients receiving care from Medicaid were at a higher risk of death compared with those in care under provisions of Ryan White Act [74]. Lack of insurance after adjustment for sociodemographic and clinical variables was also associated with a reduced relative risk of death as compared with having private insurance in a cohort of persons diagnosed with HIV/AIDS [77]. Recent studies, however, indicated that lack of health insurance or having Medicaid or Medicare compared with private insurance increased the risk of death $[80,85,87,88]$. However, adjustments for the patients' age and the disease stage were found only in two studies $[80,85]$. Such adjustment of the measure of association is important because Medicare eligibility is based on age or disability status and it would be expected that people receiving Medicare would be at higher risk of death due to the facts of being older or with more advanced disease.

\section{Studies comparing pre- and post-HAART periods}

Two reports compared mortality among persons diagnosed with HIV/AIDS before and after introduction of HAART based on arealevel of SES. For both periods, no association was found in a San Francisco study between neighborhood median household income and risk of mortality in HIV-infected patients after adjustment for relevant variables including use of HAART [35]. However, an Italian study assessing SES by composite index indicated that in the postHAART period, living in a deprived area increased risk of death among PWA after adjustment for a set of variables but not HAART use [34]. In addition to the use of various dimensions of SES, the presentation of crude measures of association, and analysis of different arrays of potential confounders allowed us to conclude that interpretation and evaluation of the results of the studies included in this review largely depend on the researchers' conceptual approach.

\section{Discussion}

Socioeconomic factors have been examined and postulated as an explanation for unfavorable health outcomes and excess burden 
Citation: Pavlova-McCalla E, Trepka MJ, Ramirez G, Niyonsenga T (2012) Socioeconomic Status and Survival of People with Human Immunodeficiency Virus Infection before and after the Introduction of Highly Active Antiretroviral Therapy: A Systematic Literature Review. J AIDS Clinic Res 3:163. doi:10.4172/2155-6113.1000163

of chronic diseases $[89,90]$. However, the direction and strength of the relationship between SES and health status depend on how SES is defined, the outcome of interest, the demographic composition of the cohorts, and the geographic regions under studies [91]. Our review confirmed that heterogeneity of available research investigating relationship between SES and mortality risk among HIV-infected individuals preclude making definite conclusions whether SES is an independent predictor of mortality in people diagnosed with HIV/ AIDS or a modifying factor for HIV progression to death. This is the first review evaluating studies about the association between SES and mortality among people with HIV/AIDS for the periods before and after introduction of HAART. A more uniform conceptualization of the socioeconomic status both at the individual and neighborhood levels with regards to HIV is needed to better understand the role of SES on mortality of people diagnosed with HIV/AIDS.

The results of the review revealed that six studies observing subjects' survival in the pre-HAART period (including the two studies covering both periods) [34,35,70-73] did not find a statistically significant association between mortality risk and low income $[35,70]$, poor financial status [73], poverty [72], or living in a neighborhood characterized by low SES [34], and higher percent of working class population [72]. While work is the major structural link between education and income or material condition, only one report of pre-HAART period demonstrated protective effects of employment at baseline for mortality with HIV/AIDS [70]. Conflicting results regarding effects of education on mortality of HIV-infected patients [70,73] supported the notion that educational achievement at the individual level does not allow to trace the relationship with health because education has different social meaning and consequences in different times and settings [92]. In addition to variations of SES measurements, the lack of the clear effect of SES on mortality risk was likely due to the limited effectiveness of HIV treatment in the pre-HAART period and thus factors linking SES to mortality through the ability to access and negotiate health care would not have greatly influenced survival.

On the other hand, the studies of post- HAART period generally showed greater all-cause mortality and HIV/AIDS-related mortality risk for people living in neighborhoods characterized by low socioeconomic index $[34,82]$, low income $[75,83,86]$, and high levels of poverty [84]. However, this association was not statistically significant in most of the studies where adjustments of the mortality risk were made for HAART use $[35,77,88]$, suggesting that the observed advantage conferred by being high SES may be at least partly related to having better access to treatment. While four out of seven papers of postHAART period did not find increased mortality risk for people with low income $[55,77,79,87]$ four out of five studies examining effects of education showed that higher educational achievement was protective $[77,82,83,86]$.

These findings are somewhat expected, since once more effective treatment becomes available, access to care can make a difference in survival and tends to be higher for those of higher SES. Thus, SES may exhibit modifying effects on HIV/AIDS outcomes. To bring more clarity to the role of SES on mortality with HIV/AIDS, the measures of SES should be considered in the life course perspective. All studies included in the review measured SES at one time, usually adulthood. This limits understanding about how SES at individual or neighborhood-level affects HIV progression to death when patients with HIV/AIDS are not able to work and live on disability allowance, but may have higher levels of education or social support available. Reverse causation between income, employment status, and health outcomes cannot be excluded.
Furthermore, socioeconomic indicators interrelate and the difficulty of understanding what factor comes first or has larger impact on survival have been noted in other epidemiologic studies and systematic reviews $[36,89]$. Studies included in the present review did not take into account the hierarchical structure of socioeconomic indicators in terms of importance and impact degree in their data analysis.

The findings that employment at baseline significantly decreased mortality risk with HIV/AIDS before and after the introduction of HAART may reflect better baseline health among patients who were able to work. The importance of clinical staging in the analysis of survival with HIV/AIDS cannot be overstressed. People are diagnosed at different times of their disease course and socioeconomic gradients may serve as markers of the disease staging. The evidence that even in universal health care settings unemployment at baseline was highly predictive for delayed access to treatment [83] may indicate patients inability to work due to poor health at the time of presentation for HIV care. The fact that having private insurance decreased mortality in HIVinfected individuals $[80,85-88$ ] can be a marker of better health and an earlier stage of the disease when people are able to work and thus are eligible for private insurance, and have not exhausted their financial resources or insurance limits.

Fifteen of the 21 studies adjusted for one or more clinical variables at the time of diagnosis. AIDS diagnosis and CD4 cell counts point out HIV progression and, therefore, they should always be adjusted for in the survival analysis if available. In the post-HAART period, treatment variables, such as access to care and HAART adherence $[18,93,94]$ affecting disease progression must be considered along with clinical variables in relation to the patients' SES. The recent trend of an increasing proportion of older adults with more advanced HIV disease compared to younger individuals at first presentation for care $[13,16]$ also highlights the importance of adjusting measures of association for age and AIDS diagnosis in the analysis of the effects of SES on mortality and morbidity due to HIV/AIDS.

There is also a relationship between mode of HIV transmission and risk of HIV progression to AIDS and death. Persons with different risk factors (e.g. injection drug use) may have therapy adherence problems due to their behavioral and decision-making characteristics that may have grounds in low education, low incomes, unemployment, and low occupational status [18]. It has been documented that the relative survival estimates by transmission category are significantly better for males exposed through male-to-male sexual contact as compared with other transmission groups [84]. In MSM, the disease progression may take longer time as compared with IDUs [95]. However, other studies did not confirm these findings [72,96]. HIV-infected patients who stop injecting drugs can have a reduced risk of disease progression when compared with current users [73]. In the three papers [34,35,79] that included demographic information about their studied population by the transmission factor, MSM transmission mode was associated with a higher SES level while IDU was associated with a lower SES level. Thus, differentials of mortality according to SES levels may have been due to variations of disease progression in persons with different HIV risk factors.

Most of the studies measuring SES at the community level did not explicitly state if they considered the community level SES as proxies for individual SES or as measures of the social setting quality in which the HIV-infected person lives. This is important because designing intervention programs often involves targeting specific populations or addressing community needs. For instance, in the cases of employment status measured at the individual level, unemployment may mean that 
Citation: Pavlova-McCalla E, Trepka MJ, Ramirez G, Niyonsenga T (2012) Socioeconomic Status and Survival of People with Human Immunodeficiency Virus Infection before and after the Introduction of Highly Active Antiretroviral Therapy: A Systematic Literature Review. J AIDS Clinic Res 3:163. doi:10.4172/2155-6113.1000163

Page 8 of 5

the person has no marketable skills, is too sick to work, or work is not available in his/her community. In contrast, unemployment on the area-based level can indicate a loss of social support in the community due to a difficult economic situation. Ideally, multilevel studies, which measure subjects' SES at individual and community level, should be conducted to elucidate the pathways between social determinants and HIV survival. At a minimum, reporting results of studies that use areabased SES variables should explicitly state whether the measurements are meant to be proxies for individual SES level or measures of the social environment in which the individual lives [31].

Although there is a clear need for the development and validation of a measure of SES that is appropriate for studying HIV survival, the available evidence suggests that SES is not consistently and strongly associated with all-cause and disease-specific mortality risk of HIVinfected patients when access to antiretroviral therapy is considered. The synthesis of the available up-to-date knowledge on the association between SES and mortality risk among people with HIV/AIDS indicates that SES affects patients' survival to a different extent in various population groups at distinctive points of disease progression. The effects of SES on mortality due to HIV/AIDS are also likely through modifying other factors relating to disease progression, especially in the post-HAART period. Further population-based studies with clearer conceptualization of SES and preferably multilevel measurements are needed to enhance understanding of the role of socioeconomic gradients on HIV outcomes. Improved understanding of the relationship between socioeconomic disadvantages and outcomes of such life-threatening infection will provide necessary information for designing and tailoring of public health programs for specific population groups at higher risk for HIV progression and address the effects of SES on health in order to reduce mortality and avert potential years of life lost.

\section{Acknowledgements}

The project described was supported by Award Number R01MD004002 from the National Institute on Minority Health and Health Disparities at the Nationa Institutes of Health. The content is solely the responsibility of the authors and does not necessarily represent the official views of the National Institute on Minority Health and Health Disparities or the National Institutes of Health. The authors would like to thank Karma Scott, MPH, for her assistance in final manuscript preparation.

\section{References}

1. Hogg RS, O'Shaughnessy MV, Gataric N, Yip B, Craib K, et al. (1997) Decline in deaths from AIDS due to new antiretrovirals. Lancet 349: 1294

2. Murphy EL, Collier AC, Kalish LA, Assmann SF, Para MF, et al. (2001) Highly active antiretroviral therapy decreases mortality and morbidity in patients with advanced HIV disease. Ann Intern Med. 135: 17-26.

3. Nakashima AK, Fleming PL (2003) HIVIAIDS surveillance in the United States, 1981-2001. J Acquir Immune Defic Syndr 1: S68-S85.

4. Palella FJ Jr, Baker RK, Moorman AC, Chmiel JS, Wood KC, et al. (2006) Mortality in the highly active antiretroviral therapy era: changing causes of death and disease in the HIV outpatient study. J Acquir Immune Defic Syndr 43: $27-34$

5. Hariri S, McKenna MT (2007) Epidemiology of Human Immunodeficiency Virus in the United States. Clin Microbiol Rev 20: 478-488.

6. Harrison KM, Song R, Zhang X (2010) Life expectancy after HIV diagnosis based on National HIV surveillance data from 25 states, United States. J of Acquir Immune Defic Syndr 53: 124-130.

7. Centers for Disease Control and Prevention (CDC) (2011) Thirty years of HIV - 1981-2011. Mortality and Morbidity Weekly Report (MMWR) 60: 689-693.

8. J M Karon, P L Fleming, R W Steketee, K M De Cock (2001) HIV in the United States at the turn of the century: an epidemic in transition. Am J Public Health 91: 1060-1068.

9. Centers for Disease Control and Prevention (CDC) (2011) Diagnoses of HIV infection and AIDS in the United States and dependent areas, 2010. HIV Surveillance Report, 21. Atlanta, GA: US Department of Health and Human Services, CDC.

10. Centers for Disease Control and Prevention (CDC) HIVIAIDS among AfricanAmericans. Atlanta, GA: US Department of Health and Human Services, CDC.

11. Centers for Disease Control and Prevention (CDC) HIV among Hispanics/ Latinos. Atlanta, GA: US Department of Health and Human Services, CDC.

12. WISQARS [Web-based Injury Statistics Query and Reporting System] (2007) Leading Causes of Death Reports, 1999 - 2007. National Center for Injury Preservation and Control, United States, CDC

13. Althoff KN, Gebo KA, Gange SJ, Klein MB, Brooks JT, et al. (2010) CD4 count at presentation for HIV care in the United States and Canada: are those over 50 years more likely to have a delayed presentation? AIDS Res Ther 7: 45.

14. Sterne JA, May M, Costagliola D, de Wolf F, Phillips AN et al. (2009) Timing of initiation of antiretroviral therapy in AIDS-free HIV-1-infected patients: a collaborative analysis of 18 HIV cohort studies. Lancet 373: 1352-1363.

15. Thompson MA, Aberg JA, Cahn P, Montaner JS, Rizzardini G, et al. (2010) Antiretroviral treatment of adult HIV infection: 2010 recommendations of the International AIDS Society-USA panel. JAMA 304: 321-333

16. de Olalla PG, Manzardo C, Sambeat MA, Ocaña I, Knobel H, et al. (2011) Epidemiological characteristics and predictors of late presentation of HIV infection in Barcelona (Spain) during the period 2001-2009. AIDS Res Ther 8. 22

17. Handsfield HH (2011) Stones unturned: missed opportunities in STD/HIV prevention. Sex Trans Dis 38: 70-73.

18. Falagas ME, Zarkadoulia EA, Pliatsika PA, Panos G (2008) Socioeconomic status (SES) as a determinant of adherence to treatment in HIV infected patients: a systematic review of the literature. Retrovirology 5:13.

19. Mannheimer SB, Matts J, Telzak E, Chesney M, Child C, et al. (2005) Quality of life in HIV-infected individuals receiving antiretroviral therapy is related to adherence. AIDS Care 17: 10-22.

20. Friedland GH, Williams A (1999) Attaining higher goals in HIV treatment: the central importance of adherence. AIDS 1: S61-72.

21. Poundstone KE, Strathdee SA, Celentano DD (2004) The social epidemiology of human immunodeficiency virus/acquired immunodeficiency syndrome. Epidemiol Rev 26: 22-35.

22. Krieger N, Chen JT, Waterman PD, Rehkopf DH, Subramanian SV (2003) Race/ethnicity, gender, and monitoring socioeconomic gradients in health: a comparison of area-based socioeconomic measures--the public health disparities geocoding project. Am J Public Health 93: 1655-1671.

23. DeNavas-Walt C, Proctor BD, Mills RJ (2004) Income, poverty, and health insurance coverage in the United States: 2003. Washington, DC: US Census Bureau, Population Reports 60-226.

24. Laurencin CT, Christensen DM, Taylor ED (2008) HIVIAIDS and the AfricanAmerican community: a state of emergency. J Natl Med Assoc 100: 35-43.

25. Diaz T, Chu SY, Buehler JW, Boyd D, Checko PJ, et al. (1994) Socioeconomic differences among people with AIDS: results from a multistate surveillance project. Am J Prevent Med 10: 217-222.

26. Beardsley M, Clatts MC, Deren S, et al. (1992) Homelessness and HIV risk behaviors in a sample of New York City drug injectors. AIDS Public Policy $\mathrm{J}$ 7: 162-169.

27. Stephens TT, Braithwaite R, Lubin J, Colbert SJ, Carn RH (2000) Homelessness and hunger as HIV risk factors for African American male commercial sex workers. J African American Studies 5: 3-15.

28. Zierler S, Krieger N (1997) Reframing women's risk: social inequalities and HIV infection. Ann Rev Public Health 18: 401-436.

29. Oakes JM, Rossi PH (2003) The measurement of SES in health research: current practice and steps toward a new approach. Soc Sci Med 56: 769-784.

30. Braveman PA, Cubbin C, Egerter S, Chideya S, Marchi KS, et al. (2005) Socioeconomic status in health research: one size does not fit all. JAMA 294 2879-2888.

31. Galobardes B, Shaw M, Lawlor DA, Lynch JW, Davey Smith G (2006) Indicators of socioeconomic position (part 2). J Epidemiol Community Health 60: 95-101. 
Citation: Pavlova-McCalla E, Trepka MJ, Ramirez G, Niyonsenga T (2012) Socioeconomic Status and Survival of People with Human Immunodeficiency Virus Infection before and after the Introduction of Highly Active Antiretroviral Therapy: A Systematic Literature Review. J AIDS Clinic Res 3:163. doi:10.4172/2155-6113.1000163

Page 9 of 5

32. Krieger $N$ (2001) Theories for social epidemiology in the 21st century: an ecosocial perspective. Int J Epidemiol 30: 668-677.

33. Marmot M (2001) Economic and social determinants of disease. Bull World Health Organ 79: 988-989.

34. Rapiti E, Porta D, Forastiere F, Fusco D, Perucci CA (2000) Socioeconomic status and survival of persons with AIDS before and after the introduction of highly active antiretroviral therapy. Epidemiology 11: 496-501.

35. McFarland W, Chen S, Hsu L, Schwarcz S, Katz M (2003) Low socioeconomic status is associated with a higher rate of death in the era of highly active antiretroviral therapy, San Francisco. J Acquir Immune Defic Syndr 33: 96-103.

36. Newman LA, Griffith KA, Jatoi I, Simon MS, Crowe JP, et al. (2006) Metaanalysis of survival in African American and white American patients with breast cancer: ethnicity compared with socioeconomic status. J Clin Oncol 24: 13421349.

37. Ntozi JP, Lubaale YM, Nakanaabi IM (1997) AIDS mortality in Uganda: circumstances, factors and impact of death. Health Transit Rev 7: 207-224

38. Cardoso MN, Caiaffa WT, Mingoti SA; Projeto AjUDE-Brasil II (2006) AIDS incidence and mortality in injecting drug users: the AjUDE-Brasil II Project. Cad Saude Publica 22: 827-837.

39. Borrell C, Rodríguez-Sanz M, Pasarín MI, Brugal MT, García-de-Olalla P, et al. (2006) AIDS mortality before and after the introduction of highly active antiretroviral therapy: does it vary with socioeconomic group in a country with a National Health System? European J Public Health 16: 601-608.

40. Mari-Dell'Olmo M, Rodriguez-Sanz M, Garcia-Olalla P, Pasarin MI, Brugal MT, et al. (2007) Individual and community-level effects in the socioeconomic inequalities of AIDS-related mortality in an urban area of southern Europe. $J$ Epidemiol Community Health 61: 232-240.

41. Priya R, Sathyamala C (2007) Contextualising AIDS and human development: Long-term illness and death among adults in labouring low-caste groups in India. AIDS Care 19: S35-43.

42. Sánchez E, Regidor E, de la Fuente L, Luquero FJ, de Mateo S (2008) [Role of antiretroviral therapy in the reduction of the association between low educational level and AIDS-related mortality]. Med Clin (Barc) 130: 133-135.

43. Karpati AM, Bassett MT, McCord C (2006) Neighbourhood mortality inequalities in New York City, 1989-1991 and 1999-2001. J Epidemiol Community Health 60: 1060-1064.

44. Fife D, Mode C (1992) AIDS prevalence by income group in Philadelphia. J Acquir Immune Defic Syndr 5: 1111-1115.

45. Levine RS, Briggs NC, Kilbourne BS, King WD, Fry-Johnson Y, et al. (2007) Black-White mortality from HIV in the United States before and after introduction of highly active antiretroviral therapy in 1996. Am J Public Health 97: 18841892.

46. Stockwell EG, Goza FW, Luse VO (1997) Infectious disease mortality among adults by race and socioeconomic status: metropolitan Ohio, 1989-1991. Soc Biol 44: 148-152.

47. Merler E, Benvenuti A, Baldi P, Nardulli MC, Olmastroni L, et al. (1999) Socioeconomic inequalities in health in the Tuscany Longitudinal Study (SLTO): persistence and changes over time in overall mortality and selected causes (lung cancer, liver cirrhosis, AIDS and overdose). Epidemiol Prev 23: 207-214.

48. Antunes JL, Waldman EA, Borrell C (2005) Is it possible to reduce AIDS deaths without reinforcing socioeconomic inequalities in health? Int J Epidemiol 34 586-592.

49. Borrell C, Azlor E, Rodríguez-Sanz M, Puigpinós R, Cano-Serral G, et al. (2008) Trends in socioeconomic mortality inequalities in a southern European urban setting at the turn of the 21st century. J Epidemiol Community Health 62: $258-266$.

50. Regidor E, Sánchez E, de la Fuente L, Luquero FJ, de Mateo S, et al. (2009) Major reduction in AIDS-mortality inequalities after HAART: the importance of absolute differences in evaluating interventions. Soc Sci Med 68: 419-426.

51. Nolasco A, Melchor I, Pina JA, Pereyra-Zamora P, Moncho J, et al. (2009) Preventable avoidable mortality: evolution of socioeconomic inequalities in urban areas in Spain, 1996-2003. Health Place 15: 702-711.

52. Rubin MS, Colen CG, Link BG (2010) Examination of inequalities in HIVIAIDS mortality in the United States from a fundamental cause perspective. Am J Public Health 100: 1053-1059.
53. Guerreiro MF, Kerr-Pontes LR, Mota RS, Franca MC Jr, Tavora FF, et al. (2002) Survival of adult AIDS patients in a reference hospital of a metropolitan area in Brazil. Rev Saude Publica 36: 278-284.

54. Nash D, Katyal M, Shah S (2005) Trends in predictors of death due to HIVrelated causes among persons living with AIDS in New York City: 1993-2001. J Urban Health 82: 584-600.

55. Maartens G, Wood R, O'Keefe E, Byrne C (1997) Independent epidemics of heterosexual and homosexual HIV infection in South Africa--survival differences. QJM 90: 449-454.

56. Armbruster C, Kriwanek S, Vorbach H (2000) Gender-specific differences in the natural history, clinical features, and socioeconomic status of HIV-infected patients: experience of a treatment centre in Vienna. Wien Klin Wochensch 112: $754-760$.

57. Fordyce EJ, Singh TP, Nash D, Gallagher B, Forlenza S (2002) Survival rates in NYC in the era of combination ART. J Acquir Immune Defic Syndr 30: 111-118.

58. Sewankambo NK, Gray RH, Ahmad S, Serwadda D, Wabwire-Mangen F, et al. (2000) Mortality associated with HIV infection in rural Rakai District, Uganda. AIDS 14: 2391-2400.

59. Kopp C, Lang S, von Overbeck J (1999) Socio-demographic and life-style factors in a Swiss study of HIV non-progression. Schweiz Med Wochensch 129: $1397-1404$

60. Hessol NA, Kalinowski A, Benning L, Mullen J, Young M, et al. (2007) Mortality among participants in the Multicenter AIDS Cohort Study and the Women's Interagency HIV Study. Clin Infect Dis 44: 287-294

61. Dray-Spira R, Gueguen A, Persoz A, Deveau C, Lert F, et al. (2005) Temporary employment, absence of stable partnership, and risk of hospitalization or death during the course of HIV infection. J Acquir Immune Defic Syndr 40: 190-197.

62. Collazos J, Asensi V, Carton JA, Ibarra S (2009) The influence of the patients' educational levels on socioeconomic, clinical, immunological and virological endpoints. AIDS Care 21: 511-519.

63. Piketty C, Castiel P, Giral P, Lhomme JP, Boubilley D, et al. (1999) Lack of legal income is strongly associated with an increased risk of AIDS and death in HIVinfected injecting drug users. AIDS Care 11: 429-436

64. Dias SS, Andreozzi V, Martins MO, Torgal J (2009) Predictors of mortality in HIV-associated hospitalizations in Portugal: a hierarchical survival model. BMC Health Serv Res 9: 125.

65. Cook JA, Burke-Miller JK, Cohen MH, Cook RL, Vlahov D, et al. (2008) Crack cocaine, disease progression, and mortality in a multicenter cohort of HIV-1 positive women. AIDS 22: 1355-1363.

66. Hogg RS, Strathdee SA, Craib KJ, O'Shaughnessy MV, Montaner JS, et al. (1994) Lower socioeconomic status and shorter survival following HIV infection. Lancet 344: 1120-1124

67. Hurtado I, Hernández-Aguado I, Ferreros I, Lumbreras B, Pérez-Hoyos S (2008) [Effect of distinct sociodemographic variables on progression of HIV infection in a cohort of drug users]. Gac Sanit 22: 541-546.

68. Cornell M, Myer L, Kaplan R, Bekker LG, Wood R (2009) The impact of gende and income on survival and retention in a South African antiretroviral therapy programme. Trop Med Int Health 14: 722-731.

69. Lindan CP, Allen S, Serufilira A, Lifson AR, Van de Perre P, et al. (1992 Predictors of mortality among HIV-infected women in Kigali, Rwanda. Ann Intern Med 116: 320-328

70. Chaisson RE, Keruly JC, Moore RD (1995) Race, sex, drug use, and progression of human immunodeficiency virus disease. N Eng J Med 333: 751 756

71. Palombi L, Mancinelli S, Liotta G, Narciso P, Marazzi MC (1997) The impact of socio-economic factors, mental health and functional status on survival in a sample of AIDS patients. AIDS Care 9: 671-680.

72. Katz MH, Hsu L, Lingo M, Woelffer G, Schwarcz SK (1998) Impact of socioeconomic status on survival with AIDS. Am J Epidemiol 148: 282-291.

73. Lee M, Rotheram-Borus MJ (2001) Challenges associated with increased survival among parents living with HIV. Am J Public Health 91: 1303-1309.

74. Lieb S, Brooks RG, Hopkins RS, Thompson D, Crockett LK, et al. (2002) Predicting death from HIVIAIDS: a case-control study from Florida public HIV/ AIDS clinics. J Acquir Immune Defic Syndr 30: 351-358. 
Citation: Pavlova-McCalla E, Trepka MJ, Ramirez G, Niyonsenga T (2012) Socioeconomic Status and Survival of People with Human Immunodeficiency Virus Infection before and after the Introduction of Highly Active Antiretroviral Therapy: A Systematic Literature Review. J AIDS Clinic Res 3:163. doi:10.4172/2155-6113.1000163

Page 10 of 5

75. Wood E, Montaner JS, Chan K, Tyndall MW, Schechter MT, et al. (2002) Socioeconomic status, access to triple therapy, and survival from HIV-disease since 1996. AIDS 16: 2065-2072.

76. Young J, De Geest S, Spirig R, Flepp M, Rickenbach M, et al. (2004) Stable partnership and progression to AIDS or death in HIV infected patients receiving highly active antiretroviral therapy: Swiss HIV cohort study. BMJ 328: 15

77. Cunningham WE, Hays RD, Duan N, Andersen R, Nakazono TT, et al. (2005) The effect of socioeconomic status on the survival of people receiving care for HIV infection in the United States. J Health Care Poor Underserved 16 $655-676$

78. Kozinetz CA, Matusa R, Hacker CS (2006) Biologic and social determinants of sequelae and long-term survival of pediatric HIV in Romania. Ann Epidemiol 16: $593-599$

79. Palange S, Porta D, Forastiere F, Perucci CA (2005) Social inequalities in survival of people with AIDS. Epidemiol Prev 29: 26-32.

80. Jain S, Schwarcz S, Katz M, Gulati R, McFarland W (2006) Elevated risk of death for African Americans with AIDS, San Francisco, 1996-2002. J Health Care Poor Underserved 17: 493-503.

81. Delpierre C, Cuzin L, Lauwers-Cances V, Datta GD, Berkman L, et al. (2008) Unemployment as a risk factor for AIDS and death for HIV-infected patients in the era of highly active antiretroviral therapy. Sex Transm Infect 84: 183-186.

82. Liotta G, Caleo GM, Mancinelli S (2008) Analysis of survival in HIV-infected subjects according to socio-economic resources in the HAART era. Ann Ig 20: 95-104.

83. Joy R, Druyts EF, Brandson EK, Lima VD, Rustad CA, et al. (2008) Impact of neighborhood-level socioeconomic status on HIV disease progression in a universal health care setting. J Acquir Immune Defic Syndr 47: 500-505.

84. McDavid Harrison K, Ling Q, Song R, Hall HI (2008) County-level socioeconomic status and survival after HIV diagnosis, United States. Ann Epidemiol 18: 919 927.

85. Chen SY, Moss WJ, Pipkin SS, McFarland W (2009) A novel use of AIDS surveillance data to assess the impact of initial treatment regimen on survival. Int J STD AIDS 20: 330-335.
86. Druyts EF, Rachlis BS, Lima VD, Harvard SS, Zhang W, et al. (2009) Mortality is influenced by locality in a major HIVIAIDS epidemic. HIV Med 10: 274-281.

87. Silverberg MJ, Leyden W, Quesenberry CP Jr, Horberg MA (2009) Race/ ethnicity and risk of AIDS and death among HIV-infected patients with access to care. J Gen Intern Med 24: 1065-1072.

88. Arnold M, Hsu L, Pipkin S, McFarland W, Rutherford GW (2009) Race, place and AIDS: the role of socioeconomic context on racial disparities in treatment and survival in San Francisco. Soc Sci Med 69: 121-128.

89. Lorant V, Deliège D, Eaton W, Robert A, Philippot P, et al. (2003) Socioeconomic inequalities in depression: a meta-analysis. Am J Epidemiol 157: 98-112.

90. Baquet CR, Commiskey P (2000) Socioeconomic factors and breast carcinoma in multicultural women. Cancer 88: 1256-1264.

91. Ross NA, Wolfson MC, Dunn JR, Berthelot JM, Kaplan GA, et al. (2000) Relation between income inequality and mortality in Canada and in the United States: cross sectional assessment using census data and vital statistics. BM 320: 898-902.

92. Lynch J, Kaplan GA (2000) Socioeconomic position. In: Berkman LF, Kawachi I editors. Social Epidemiology. Oxford University Press New York.

93. Turner BJ, Laine C, Cosler L, Hauck WW (2003) Relationship of gender depression, and health care delivery with antiretroviral adherence in HIVinfected drug users. J Gen Intern Med 18: 248-257.

94. Turner BJ (2002) Adherence to antiretroviral therapy by human immunodeficiency virus-infected patients. J Infect Dis 2: S143-151.

95. Malta M, Bastos FI, da Silva CM, Gerson Fernando MP, Francisca FAL, et al. (2009) Differential survival benefit of universal HAART access in Brazil: a nation-wide comparison of injecting drug users versus men who have sex with men. J Acquir Immune Defic Syndr 52: 629-635.

96. Vella S, Giuliano M, Floridia M, Chiesi A, Tomino C, et al. (1995) Effect of sex age and transmission category on the progression to AIDS and survival of zidovudine-treated symptomatic patients. AIDS 9: 51-56. 